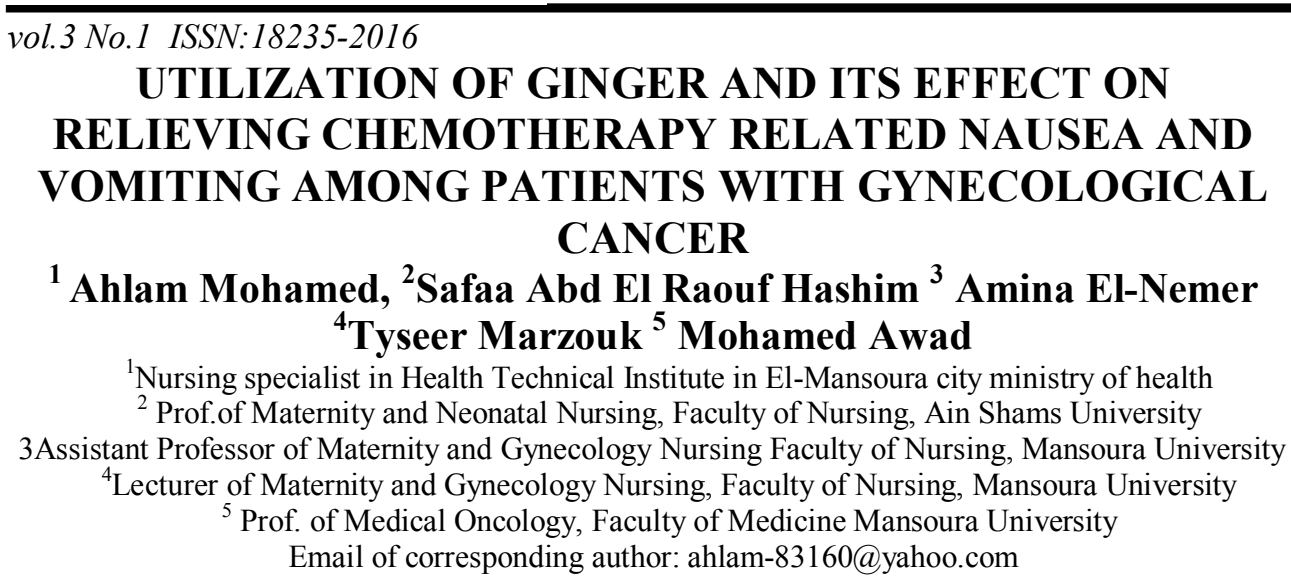

${ }^{1}$ Nursing specialist in Health Technical Institute in El-Mansoura city ministry of health

${ }^{2}$ Prof.of Maternity and Neonatal Nursing, Faculty of Nursing, Ain Shams University

3Assistant Professor of Maternity and Gynecology Nursing Faculty of Nursing, Mansoura University

${ }^{4}$ Lecturer of Maternity and Gynecology Nursing, Faculty of Nursing, Mansoura University

${ }^{5}$ Prof. of Medical Oncology, Faculty of Medicine Mansoura University Email of corresponding author: ahlam-83160@yahoo.com

\begin{abstract}
:
Aim: to explore the utilization of ginger and its effect on relieving the chemotherapy related nausea and vomiting among patients with gynecological cancer. Methods: An quasi-experimental research design was utilized to conduct this study on 132 patients attended the oncology center of Mansoura University Hospital between January 2013 to December 2013 for chemotherapy for a gynecologic tumor. The study sample served as a one arm intervention group. Data were collected using three tools; the 1st tool was an interview questionnaire to assess the general characteristics of the patients, the 2nd tool was the Rhodes Inventory of Nausea, Vomiting and Retching (INVR) to assess the level and severity of nausea and vomiting experienced before and after the chemotherapy and the 3rd tool was the woman's follow up card to assess the patient's compliance with the ginger tablets. Results: The baseline total Rhodes Index score was significantly decreased after receiving the assigned dose of Ginger tablets $(63.8 \pm 5.3$ at base line and $60.6 \pm 4.9$ at end of the study $\mathrm{P}<0.0001)$. Conclusion: Ginger tablets are effective in reducing the chemotherapy induced nausea and vomiting.

Key word: Ginger tablets, chemotherapy induced nausea and vomiting, gynecologic tumor, Rhodes Inventory of nausea and vomiting.
\end{abstract}

\title{
Introduction:
}

Chemotherapy-induced nausea and vomiting (CINV) is the commonest despite the widespread use of antiemetic medication. (1) Nausea and/or vomiting occur in 50 to $70 \%$ of people with advanced cancer. It is an important source of anxiety and severely affects patient's quality of life. (2)

Cancer patient's experiencing CINV not only during chemotherapy but also after treatment (3) CINV could lead to dose reduction or resulting in treatment discontinuation, which increase the risk of disease progression (4) CINV could raise medical complication which increase the cost of medical care. There is some factors influence the individual at risk for CINV. These factors; patient's lifestyle, mental state, and previous experience with nausea and vomiting in other settings and the major determinant of CINV risk, the emetogenicity of the chemotherapy treatment (5) Being a female and age under 50 are the most indicators of 
CINV and ANV (6) CINV are classified as: Acute which occurs within 24 hours of chemotherapy, Delayed which occurs between 24 hours and 5 days after treatment, the impact of new antiemetic on incidence of Aticipatory Nausea and vomiting is unclear and Repeated exposure to chemotherapy increases risk for the development of $\operatorname{ANV(5).~}$

Data suggests efficacy for alternative medicines for relief of symptoms. Ginger root is the rhizome of the plant Zingiber officinale (ZO), consumed as a delicacy, medicine or spice. Ginger root Conventional antiemetics are more successful at preventing emesis than in preventing nausea. The benefit of ginger (Zingiber officinale) as an aid to reduce nausea during chemotherapy was addressed.

\section{Research hypothesis}

Women on chemotherapy for gynecologic tumors who consume Ginger tablets exhibits lower score of Rhodes for nausea and vomiting after receiving the treatment.

\section{Subjects and Method}

Research design: An quasiexperimental research design was utilized.

Study Setting: This study was conducted at the Oncology Center of Mansoura University Hospital, Mansoura city. between the periods of Jaunuary 2013 to december 2013.

Subjects: A purposive sample of 132 eligible women who were attended Oncology Center of Mansoura
University hospital for treatment from January to December 2013.

Inclusion criteria:

1- Diagnosed with gynecological tumor.

2- Aged between 30 to 70 years old

3- On the same type and dose of chemotherapeutic agents.

4- Normotensive

5- Agreed to participate in the research.

Exclusion criteria: radiological treatment

\section{Sample size:}

Sample size for the current study was calculated by assuming $\alpha$ risk to equal $10 \%$ and the desired power is $60 \%$, when the assumed number of nausea and vomiting in women receiving placebo would be reduced from $57 \%$ according to reviewed literatures to $38 \%$ (Densak Pongrojpaw and Densak 2006). The minimum required subjects by considering drop outs by adding $10 \%$ are 132 women (Joseph L. Fliess 1981). (14)

\section{Tools of Data Collection:}

Three tools were used for data collection.

\section{Tool I. Interview questionnaire}

The interview questionnaire designed to collect the necessary data from the enrolled women. It entails the following parts:

Part 1. General characteristics of the enrolled women including; age, occupation, educational level, marital 
UTILIZATION OF GINGER AND ITS EFFECT ON RELIEVING etc...

status, residence and telephone number.

Part 2. Designed to assess cancer history (site of cancer, time of chemotherapy initiation)

\section{Tool II: Rhodes Inventory of Nausea, Vomiting and Retching (INVR)}

It is a self-report questionnaire that measures nausea, vomiting and retching as separate entities based on 8 items with 5-points Likert scale that modified to three point (Rhodes VA, McDaniel RW, 1999). The frequency and distress of all entities were measured as well as the duration of nausea and the amount of vomiting. This tool is suitable for use during each phase of CINV (i.e. anticipatory, acute, and delayed) and it was used to measure symptoms over a 12 hour period and to assess the degree of nausea and vomiting before and after receiving ginger tablet.

\section{Tool III: Woman's follow up card:}

It was designed to assess women's compliance with ginger tablets.

\section{Ethical Considerations:}

1- Permission to carry out the study obtained from the responsible authorities at Oncology Center Mansoura University Hospital.

2. Ethical approval obtained from the Research Ethics Committee of the Faculty of Nursing - Mansoura University.

3- Participation in this study was voluntary. Each participant has the right to withdraw from the study at any time without consequence.

4- Confidentiality of the collected data has been maintained.

5- The results used as a component of the necessary research for doctoral thesis, as well as for future publications and education.

\section{Field Work:}

1- During the study period, the researcher attended the study setting from 9 am to $2 \mathrm{pm}$ for four days per week.

2- The researcher met each woman individually introduced herself to each participant and to support person, a full explanation about and scope of the study was given to obtain woman's acceptance and informed consent.

3- The researcher explained the study purpose to the woman and her family accompanier and starts to fill in the questionnaire.

4- The researcher provided each participant with an Arabic copy of Rhodes scale to fill-in before and immediately after chemotherapy treatment to assess the degree of nausea and vomiting before intervention this was the base line data.

5- Then the researcher collected the copy of Rhodes scale and coded it.

6- During the second visit: complete prescription of ginger was given regarding its components, importance and widely used as a 
drink or a kitchen spice in addition it has antiemetic properties.

7- After taken physician approval, each woman / supported person was given 10 ginger tablets from the researcher with a written prescription paper and complete instruction was given on its use. In terms of before starting the next chemotherapy session to at least 2 consecutive sessions, one tablet before starting the next chemotherapy session, one tablet after the session, one tablet after $24 \mathrm{~h}$ and the last one within $72 \mathrm{hrs}$ after session. Each tablet contained $400 \mathrm{mg}$ dry extract of ginger root extraction

8- Maximum consumed ginger tablets was 10 tablets.

9- The eligible participants received another Arabic copy of Rhodes scale and women's follow up card to monitor their compliance with the assigned doses of ginger. Their answers were provided to the researcher during their next clinic visit and these data represent post intervention data.

\section{Results}

10- Table 1 shows the frequency distribution of socio-demographic characteristics among the study group. The mean age of studied sample was $52.8 \pm 11.0$. The same table also reveals that the highly distributed marital status was the married $(71.2 \%)$, while the highly distributed education level was illiterate $(67.4 \%)$. As regard to occupation; housewife was the highly distributed (93.9\%).

Women from rural origin were more than those from urban origin $(65.9 \%$ vs. $43.1 \%)$.

\begin{tabular}{|c|c|c|}
\hline \multirow{2}{*}{$\begin{array}{c}\text { Socio- } \\
\text { demographic } \\
\text { characteristics }\end{array}$} & \multicolumn{2}{|c|}{$\begin{array}{c}\text { Study sample } \\
\quad(n=132)\end{array}$} \\
\hline & No. & $\%$ \\
\hline $\begin{array}{l}\text { Age (years) } \\
\text { Mean } \pm \text { SD } \\
52.8 \pm 11.0\end{array}$ & & \\
\hline $\begin{array}{l}\text { Marital status } \\
\text { Married } \\
\text { Divorced } \\
\text { Widowed }\end{array}$ & $\begin{array}{c}94 \\
4 \\
34\end{array}$ & $\begin{array}{c}71.2 \\
3.0 \\
25.8\end{array}$ \\
\hline $\begin{array}{l}\text { Level of } \\
\text { education } \\
\text { Illiterate } \\
\text { Primary / } \\
\text { preparatory } \\
\text { Secondary } \\
\text { /university } \\
\end{array}$ & $\begin{array}{l}89 \\
21\end{array}$ & $\begin{array}{l}67.4 \\
15.9\end{array}$ \\
\hline $\begin{array}{c}\text { Occupation } \\
\text { Working } \\
\text { Housewife } \\
\end{array}$ & $\begin{array}{c}8 \\
124 \\
\end{array}$ & $\begin{array}{c}6.1 \\
93.9 \\
\end{array}$ \\
\hline $\begin{array}{l}\text { Residence } \\
\text { Urban } \\
\text { Rural }\end{array}$ & $\begin{array}{l}45 \\
87\end{array}$ & $\begin{array}{l}34.1 \\
65.9\end{array}$ \\
\hline
\end{tabular}

Figure 1 shows the frequency distribution of the study sample according to the site of tumor. It is obvious that the majority of the studied sample diagnosed with ovarian tumours $78 \%$ followed by uterine other location (11.40\%., 10.60\%). 
UTILIZATION OF GINGER AND ITS EFFECT ON RELIEVING etc...

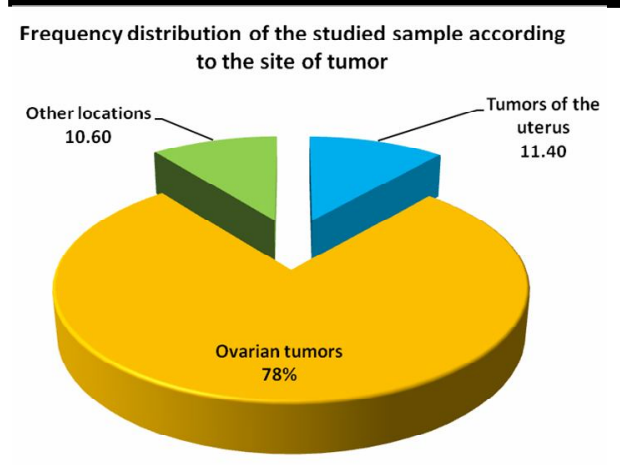

Figure2 Show frequency distribution of the studied sample according to the duration of receiving chemotherapy. It's clear from this figure that slightly more than half $(50.7 \%)$ of women had received chemotherapy for a duration ranged from 1-6 months, $28.8 \%$ of women had received chemotherapy for a period extended from 6 months to one year while slightly more than one fifth $(20.5 \%)$ of women had received chemotherapy for more than one year.

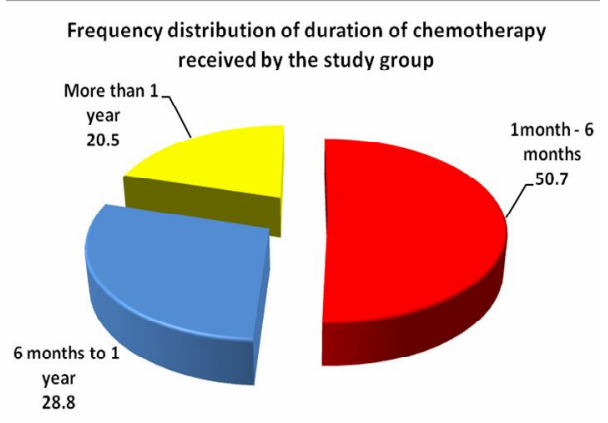


Ahlam Mohamed et. al.

Table (5): Rhodes Index for the nausea and vomiting among the study sample pre and post receiving the ginger tablets

\begin{tabular}{|c|c|c|c|c|c|}
\hline \multirow{3}{*}{ Rhodes Index Items } & \multicolumn{4}{|c|}{ Studied women $(n=132)$} & \multirow{3}{*}{ Significance } \\
\hline & \multicolumn{2}{|c|}{ Before ginger } & \multicolumn{2}{|c|}{ After Ginger } & \\
\hline & No. & $\%$ & No. & $\%$ & \\
\hline $\begin{array}{l}\text { Number of throwing up } \\
\geq 5 \text { times } \\
1-4 \text { times } \\
\text { None }\end{array}$ & $\begin{array}{l}39 \\
78 \\
15\end{array}$ & $\begin{array}{l}29.5 \\
59.1 \\
11.4\end{array}$ & $\begin{array}{c}6 \\
76 \\
50\end{array}$ & $\begin{array}{l}4.5 \\
57.6 \\
37.9\end{array}$ & $\begin{array}{l}\mathrm{MH}=8.412 \\
\mathrm{P}<0.0001 *\end{array}$ \\
\hline $\begin{array}{l}\text { Feeling distress after retching or } \\
\text { dry heaves by } 6 \text { hrs } \\
\text { Severe } \\
\text { Mild-Moderate } \\
\text { No }\end{array}$ & $\begin{array}{l}66 \\
64 \\
2\end{array}$ & $\begin{array}{l}50 \\
48.5 \\
1.5\end{array}$ & $\begin{array}{r}10 \\
84 \\
38\end{array}$ & $\begin{array}{c}7.6 \\
63.8 \\
28.8\end{array}$ & $\begin{array}{l}\mathrm{MH}=9.208 \\
\mathrm{P}<0.0001 *\end{array}$ \\
\hline $\begin{array}{l}\text { Feel distress after vomiting by } 6 \text { hrs } \\
\text { Severe } \\
\text { Moderate- Mild } \\
\text { No }\end{array}$ & $\begin{array}{l}63 \\
6 \\
3\end{array}$ & $\begin{array}{c}47.8 \\
49.9 \\
2.3\end{array}$ & $\begin{array}{c}8 \\
96 \\
28\end{array}$ & $\begin{array}{c}6.1 \\
72.7 \\
21.2\end{array}$ & $\begin{array}{l}\mathrm{MH}=8.939 \\
\mathrm{P}<0.0001 *\end{array}$ \\
\hline $\begin{array}{l}\text { Feel nauseated or sick at the } \\
\text { stomach in the last } 6 \mathrm{hrs} \\
\geq 4 \text { hours } \\
1-3 \text { hours } \\
\text { Not at all }\end{array}$ & $\begin{array}{c}73 \\
57 \\
2\end{array}$ & $\begin{array}{c}55.3 \\
43.2 \\
1.5\end{array}$ & $\begin{array}{c}6 \\
97 \\
29\end{array}$ & $\begin{array}{l}4.5 \\
73.5 \\
22.0\end{array}$ & $\begin{array}{l}\mathrm{MH}=9.055 \\
\mathrm{P}<0.0001 *\end{array}$ \\
\hline $\begin{array}{l}\text { Feel distress after nausea/sickness at } \\
\text { stomach by } 6 \mathrm{hrs} \\
\text { Severe } \\
\text { Mild- Moderate } \\
\text { No }\end{array}$ & $\begin{array}{c}82 \\
47 \\
3\end{array}$ & $\begin{array}{c}62.2 \\
35.5 \\
2.3\end{array}$ & $\begin{array}{l}13 \\
95 \\
24\end{array}$ & $\begin{array}{c}9.8 \\
72.0 \\
18.2\end{array}$ & $\begin{array}{l}\mathrm{MH}=8.673 \\
\mathrm{P}<0.0001 *\end{array}$ \\
\hline $\begin{array}{l}\text { Amount of vomiting or throwing in } \\
\text { last } 6 \text { hrs } \\
\text { Large- very large } \\
\text { Small- moderate } \\
\text { None }\end{array}$ & $\begin{array}{l}58 \\
36 \\
38\end{array}$ & $\begin{array}{l}43.9 \\
27.3 \\
28.8\end{array}$ & $\begin{array}{l}9 \\
66 \\
57\end{array}$ & $\begin{array}{c}6.8 \\
50 \\
43.2\end{array}$ & $\begin{array}{c}\mathrm{MH}=3.173 \\
\mathrm{P}=0.002^{*}\end{array}$ \\
\hline $\begin{array}{l}\text { Frequency of feeling nausea or } \\
\text { sick at stomach in last } 6 \mathrm{hrs} \\
\geq 5 \text { times } \\
1-4 \text { times } \\
\text { No } \\
\end{array}$ & $\begin{array}{l}58 \\
72 \\
2\end{array}$ & $\begin{array}{l}43.9 \\
54.6 \\
1.5\end{array}$ & $\begin{array}{c}10 \\
102 \\
20\end{array}$ & $\begin{array}{c}7.5 \\
77.3 \\
15.2\end{array}$ & $\begin{array}{l}\mathrm{MH}=8.283 \\
\mathrm{P}<0.0001 *\end{array}$ \\
\hline $\begin{array}{l}\text { Frequency of retching or dry heaves } \\
\text { without vomiting in last } 6 \mathrm{hrs} \\
\geq 5 \text { times } \\
1-4 \text { times } \\
\text { No }\end{array}$ & $\begin{array}{l}61 \\
69 \\
2\end{array}$ & $\begin{array}{c}46.3 \\
52.2 \\
1.5\end{array}$ & $\begin{array}{l}10 \\
98 \\
24\end{array}$ & $\begin{array}{c}7.6 \\
74.2 \\
18.2\end{array}$ & $\begin{array}{c}\mathrm{MH}=8.12 \\
\mathrm{P}<0.0001 *\end{array}$ \\
\hline
\end{tabular}

MH: Marginal Homogeneity test $\quad$ *significant at $\mathrm{P} \leq 0.05$

Table (2): Represents comparison (SCG) group regarding alopecia between control group and study questions that all women (100\%) in 
UTILIZATION OF GINGER AND ITS EFFECT ON RELIEVING etc...

control group and the majority of the women $(96.7 \%)$ in the studygroup(SCG) were suffered from hair loss, and all the women (100\%) in both groups suffering hair loss more than a month. There is no significant difference between the study group (SCG) \& the control group regarding alopecia questions $(\mathrm{P}<0.05)$.As regard to the degree of hair loss according to WHO scaling system for hair loss there is highly significance difference between the two groups regarding degree of hair loss $(p=.000)$ as in the control group there were (46.7\%) suffering total alopecia in comparison to study group (SCG) there were $(3.3 \%)$ suffering total alopecia .This means that the study group (scalp cooling group) suffered less hair loss after receiving scalp cooling than the control group who receive the routine hospital care.

Table (2): comparison between control group and study group regarding alopecia questions

\begin{tabular}{|c|c|c|c|c|c|c|}
\hline \multirow[t]{2}{*}{ Alopecia questions } & \multicolumn{2}{|c|}{$\begin{array}{c}\text { Control group } \\
(\mathbf{N}=\mathbf{3 0})\end{array}$} & \multicolumn{2}{|c|}{$\begin{array}{c}\text { Study group } \\
(\mathrm{No}=\mathbf{3 0})\end{array}$} & \multirow[t]{2}{*}{$\mathbf{X}^{2}$} & \multirow[t]{2}{*}{$P$ - value } \\
\hline & No & $\%$ & No & $\%$ & & \\
\hline $\begin{array}{l}\text { Suffering from hair loss:- } \\
\text { Yes } \\
\text { No }\end{array}$ & $\begin{array}{c}30 \\
0\end{array}$ & $\begin{array}{c}100.0 \% \\
.0 \%\end{array}$ & $\begin{array}{c}29 \\
1\end{array}$ & $\begin{array}{l}96.7 \% \\
3.3 \%\end{array}$ & 1.017 & .313 \\
\hline$\frac{\text { Time of hair loss:- }}{\text { More than a month }}$ & 30 & $100.0 \%$ & 30 & $\begin{array}{c}100.0 \\
\%\end{array}$ & - & - \\
\hline $\begin{array}{l}\text { Degree of hair loss:- } \\
\text { 0-Not significant hair loss } \\
\text { 1-Minor hair loss not } \\
\text { requiring a wig } \\
\text { 2-Moderate hair loss not } \\
\text { requiring a wig } \\
\text { 3-sever hair loss, requiring } \\
\text { a wig } \\
\text { 4- Total alopecia }\end{array}$ & $\begin{array}{l}0 \\
0 \\
4\end{array}$ & $\begin{array}{l}40.0 \% \\
43.3 \%\end{array}$ & $\begin{array}{c}1 \\
19 \\
6\end{array}$ & $\begin{array}{l}3.3 \% \\
63.3 \% \\
20.0 \%\end{array}$ & $\begin{array}{c}37.06 \\
7\end{array}$ & $.000 * *$ \\
\hline $\begin{array}{l}\text { Other scalp problems } \\
\text { before chemotherapy: } \\
\text { No }\end{array}$ & 30 & $\begin{array}{l}100.0 \\
\%\end{array}$ & 30 & $\begin{array}{c}100.0 \\
\%\end{array}$ & - & - \\
\hline \multicolumn{7}{|c|}{$\begin{array}{l}\text { Table (3): Represents the prevalence } \\
\text { of scalp cooling side effect, where } \\
\text { during doing this procedure. And } \\
100 \% \text { of study group(scalp cooling } \\
\text { group) suffered from feeling cold and } 100 \% \text { are suffering from headache and } \\
\text { feel boring }\end{array}$} \\
\hline
\end{tabular}


Table (3):Prevalence of side effects of scalp cooling among scalp cooling group.

\begin{tabular}{|l|c|c|}
\hline \multirow{2}{*}{ Scalp cooling side effects } & \multicolumn{2}{|c|}{$\begin{array}{c}\text { Study group } \\
\text { (No =30) }\end{array}$} \\
\cline { 2 - 3 } & No & \% \\
\hline Feeling cold:- & 30 & $100.0 \%$ \\
Yes & 0 & $0 \%$ \\
No & 21 & $70.0 \%$ \\
\hline Blanket for warmth:- & 9 & $30.0 \%$ \\
\hline Yes & 30 & $100.0 \%$ \\
No & 0 & $0 \%$ \\
\hline Headache :- & & $100.0 \%$ \\
\hline Yes & 30 & 0 \\
\hline Fo & 0 & \\
\hline Yeeling boring:- & & \\
No & & \\
\hline
\end{tabular}

Table (4): Represents comparison between control group and study group(SCG) in grades of hair loss before the first cycle and after the six cycle of chemotherapy there were $(63.3 \% \& 0 \%)$ have grade1 from the study group (SCG)andcontrol group respectively. While there were
$(43.3 \% \& 3.3 \%)$ have grade 4 (total alopecia) from the control group and study group(SCG) respectively after the six cycle of chemotherapy. There is highly significance difference between the two groups regarding grades of hair loss. $\mathrm{P}<.05$

Table (4): Comparison between control group \&study group (scalp cooling group) in grades of hair loss according to WHO before the first cycle and after the six cycle of chemotherapy.

\begin{tabular}{|c|c|c|c|c|c|c|c|c|c|c|c|c|}
\hline \multirow{3}{*}{$\begin{array}{c}\text { Grades of } \\
\text { hair loss }\end{array}$} & \multicolumn{4}{|c|}{$\begin{array}{c}\text { Control group } \\
\end{array}$} & \multicolumn{4}{|c|}{ Study group (SCG) } & \multicolumn{2}{|l|}{$\mathrm{X}^{2}$} & \multicolumn{2}{|c|}{ P - value } \\
\hline & \multicolumn{2}{|c|}{$\begin{array}{c}\text { Before cycle } \\
1\end{array}$} & \multicolumn{2}{|c|}{ After cycle 6} & \multicolumn{2}{|c|}{$\begin{array}{l}\text { Before } \\
\text { cycle } 1\end{array}$} & \multicolumn{2}{|c|}{ After cycle 6} & \multirow[t]{2}{*}{$\begin{array}{l}\text { Before } \\
\text { cycle } 1\end{array}$} & \multirow[t]{2}{*}{$\begin{array}{l}\text { After } \\
\text { cycle } 6\end{array}$} & \multirow{2}{*}{$\begin{array}{c}\text { Befor } \\
\text { e cycle } \\
1 \\
\end{array}$} & \multirow[t]{2}{*}{$\begin{array}{c}\text { After } \\
\text { cycle } 6\end{array}$} \\
\hline & No & $\%$ & No & $\%$ & No & $\%$ & No & $\%$ & & & & \\
\hline $\mathbf{0}$ & 30 & $100 \%$ & 0 & $0 \%$ & 30 & 100 & 1 & $3.3 \%$ & 1.017 & 35.777 & .313 & $.000 * *$ \\
\hline 1 & 0 & $0 \%$ & 0 & $0 \%$ & 0 & & 19 & $63.3 \%$ & & & & \\
\hline 2 & & & 5 & $16.7 \%$ & & & 6 & $20.0 \%$ & & & & \\
\hline 3 & & & 12 & $40.0 \%$ & & & 3 & $10.0 \%$ & & & & \\
\hline 4 & & & 13 & $43.3 \%$ & & & 1 & $3.3 \%$ & & & & \\
\hline
\end{tabular}


Table (5):Represents the relation between the type of chemotherapy and grades of hair loss after the sixth cycle of chemotherapy in both control group and study group (SCG) that there were $40 \%$ from the women treated withTaxol-carpolinatein study group have gradeI hair loss and also $40 \%$ have grade II hair loss while $60 \%$ from the women who treated with taxolcarpolinate in the control group have grade III hair loss. In relation to the women treated withFAC(FloururacilAdriamycin-

Table (5) The relation between grades of hair loss and type of chemotherapy after the six cycle of chemotherapy among study group (scalp cooling group) and control group.

\begin{tabular}{|c|c|c|c|c|c|c|c|c|c|c|c|c|c|c|c|c|}
\hline \multirow{3}{*}{$\begin{array}{c}\text { Grades } \\
\text { of hair } \\
\text { loss }\end{array}$} & \multicolumn{6}{|c|}{ Type of chemotherapy in SCG group } & \multicolumn{6}{|c|}{ Type of chemotherapy in control group } & & & & \\
\hline & \multicolumn{2}{|c|}{$\begin{array}{c}\text { Taxol- } \\
\text { carpolinate }\end{array}$} & \multicolumn{2}{|c|}{$\begin{array}{c}\text { FAC(Floururacil- } \\
\text { Adriamycin- } \\
\text { Cyclophosphamide } \\
\text { \{Endoxan\}) } \\
\end{array}$} & \multicolumn{2}{|c|}{ Foulox } & \multicolumn{2}{|c|}{$\begin{array}{c}\text { Taxol- } \\
\text { carpolinate }\end{array}$} & \multicolumn{2}{|c|}{$\begin{array}{c}\text { FAC(Floururacil- } \\
\text { Adriamycin- } \\
\text { Cyclophosphamide } \\
\text { \{Endoxan\}) } \\
\end{array}$} & \multicolumn{2}{|c|}{ Foulox } & \multicolumn{2}{|c|}{$\mathrm{X}^{2}$} & \multicolumn{2}{|c|}{$P$-value } \\
\hline & No & $\%$ & No & $\%$ & $\mathrm{~N}$ & $\%$ & No & $\%$ & No & $\%$ & No & $\%$ & SCG & Control & SCG & Control \\
\hline $\begin{array}{c}\text { Grade } \\
0\end{array}$ & 0 & $0 \%$ & 0 & $0 \%$ & 1 & $10.0 \%$ & - & - & - & - & - & - & & & & \\
\hline $\begin{array}{c}\text { Grade } \\
1\end{array}$ & 2 & $40.0 \%$ & 9 & $60.0 \%$ & 8 & $80.0 \%$ & - & - & - & - & - & - & & & & \\
\hline $\begin{array}{c}\text { Grade } \\
2\end{array}$ & 2 & $40.0 \%$ & 3 & $20.0 \%$ & 1 & $10.0 \%$ & 1 & $20.0 \%$ & 1 & $5.9 \%$ & 3 & $37.5 \%$ & 7.061 & 15.962 & .530 & $.003 *$ \\
\hline $\begin{array}{c}\text { Grade } \\
3\end{array}$ & 1 & $20.0 \%$ & 2 & $13.3 \%$ & 0 & $0 \%$ & 3 & $60.0 \%$ & 4 & $23.5 \%$ & 5 & $62.5 \%$ & & & & \\
\hline $\begin{array}{c}\text { Grade } \\
4\end{array}$ & 0 & $0 \%$ & 1 & $6.7 \%$ & 0 & $0 \%$ & 1 & $20.0 \%$ & 12 & $70.6 \%$ & 0 & $0 \%$ & & & & \\
\hline
\end{tabular}

Table (6):Represents the relation between age \& grades of hair loss after the 6th cycle among study group(scalp cooling group)(SCG) that all women whose age ranged from (18
Cyclophosphamide\{Endoxan\}) there were $60 \%$ from the women in study group(SCG)have grade I hair loss while in the control group there were $70.6 \%$ have grade IV hair loss. As regard to the women who treated with Floxthere were $80 \%$ from the women in the study group have grade I hair loss while $62.5 \%$ from the women in the control group have grade III. There were significance differences between the two groups in grades of hair loss in relation to type of chemotherapy 
loss. This means that there was a have gradeI) \& the older age women significance difference between (which they have gradeII,III,IV)and younger age women (most of them the grades of hair loss. $(\mathrm{P}<0.05)$

Table (6) Relation between age $\&$ grades of hair loss after $6^{\text {th }}$ cycle among study group (scalp cooling group).

\begin{tabular}{|c|c|c|c|c|c|c|c|c|}
\hline \multirow{3}{*}{$\begin{array}{l}\text { Grade of } \\
\text { hair loss }\end{array}$} & \multicolumn{6}{|c|}{ Age } & \multirow{3}{*}{$\mathbf{X}^{2}$} & \multirow{3}{*}{$P$ - value } \\
\hline & \multicolumn{2}{|c|}{$18<39$} & \multicolumn{2}{|c|}{$40<49$} & \multicolumn{2}{|c|}{$50<60$} & & \\
\hline & No & $\%$ & No & $\%$ & No & $\%$ & & \\
\hline Grade 0 & 0 & $0 \%$ & 1 & $7.7 \%$ & 0 & $0 \%$ & & \\
\hline Grade 1 & 12 & $100 \%$ & 6 & $46.2 \%$ & 1 & $20.0 \%$ & 17.174 & $.028 *$ \\
\hline Grade 2 & 0 & $0 \%$ & 4 & $30.8 \%$ & 2 & $40.0 \%$ & & \\
\hline Grade 3 & 0 & $0 \%$ & 2 & $15.4 \%$ & 1 & $20.0 \%$ & & \\
\hline Grade 4 & 0 & $0 \%$ & 0 & $0 \%$ & 1 & $20 \%$ & & \\
\hline
\end{tabular}

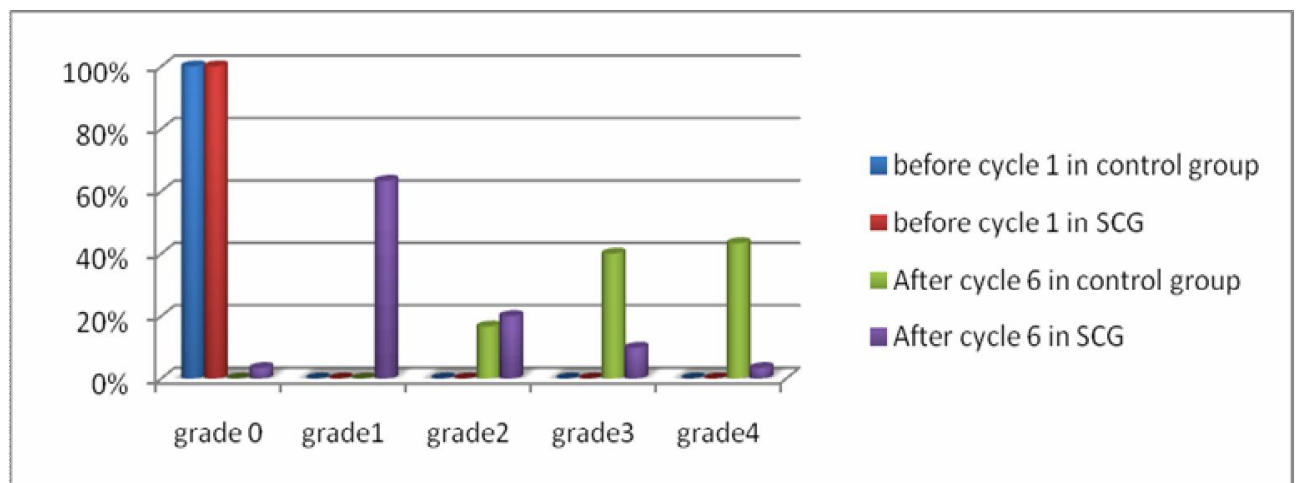

Fig (1) Comparison between control group \&study group (SCG) in grades of hair loss according to WHO before the first cycle and after the six cycle of chemotherapy. 


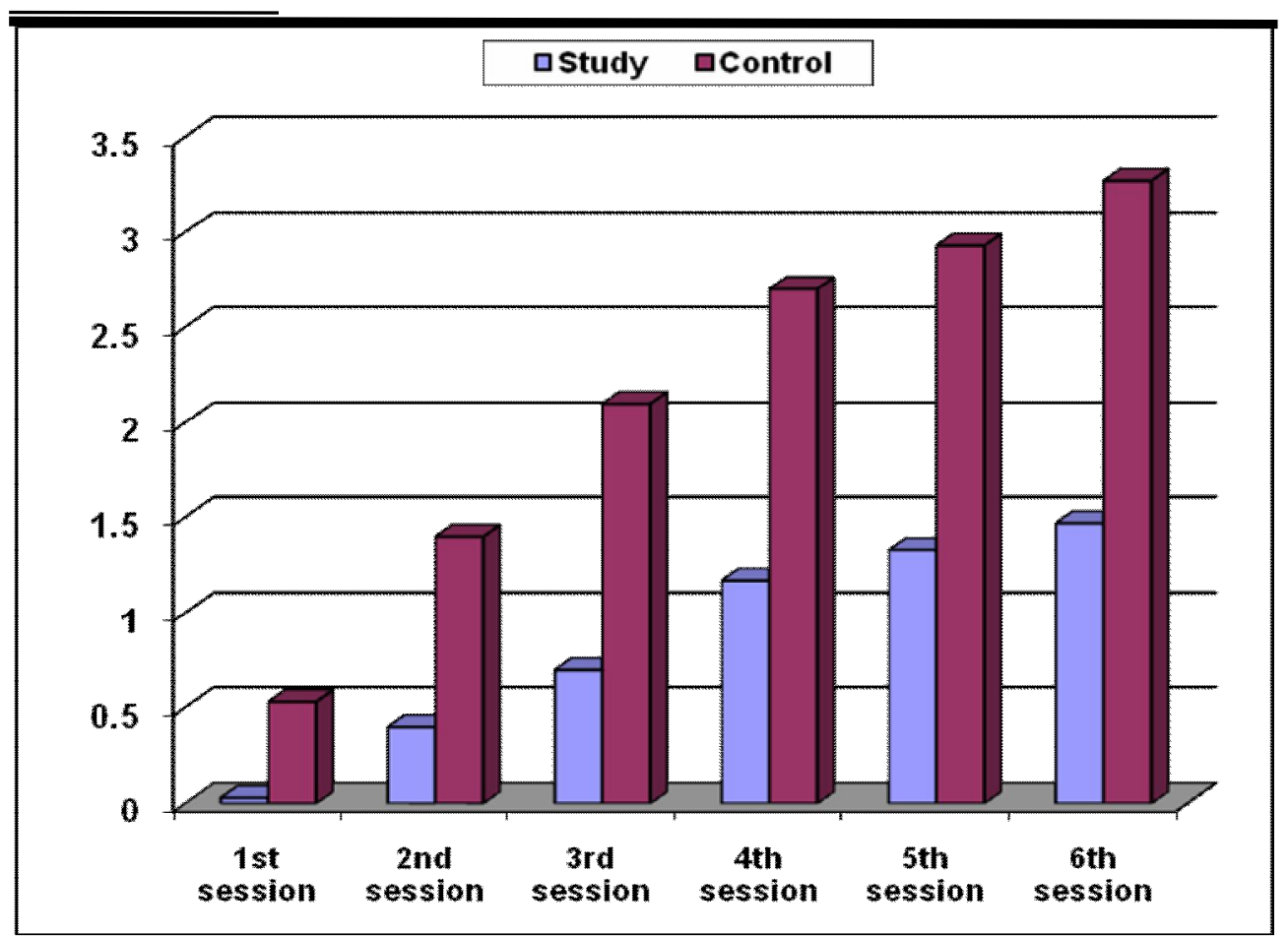

Fig (2) Comparison between the control and study group(SCG) in the six cycles of chemotherapy in relation to hair loss

Table 5 shows the Rhodes Index for the nausea and vomiting among the study sample pre and post receiving the ginger tablets. It is clear from this table that all the Rhodes Index items were highly significantly decreased after receiving the ginger tablets compared to before receiving $(p<0.001)$. Specifically, the number of throwing up $\geq 5$ was decreased from $29.5 \%$ to $4.5 \%$ post ginger use $(\mathrm{MH}=8.412)$, with a highly significantly decrease of the percentage of patients who reported a large amount of throwing up from $43.9 \%$ pre ginger use to only $6.8 \%$ post use. The percentage of patients who were reported $\geq 5$ times of feeling retching in the last 6 hours was decreased from $46.3 \%$ to $7.6 \%$ after ginger use, with only $7.6 \%$ reported feeling severe distress after retching compared to $50 \%$ before the ginger use $(\mathrm{MH}=$ 9.208). However, the percentage of patients who were reported $\geq 5$ times of feeling nausea in the last 6 hours was decreased from $43.9 \%$ to $7.5 \%$ after ginger use, with only $9.8 \%$ reported feeling severe distress after nausea compared to $62.2 \%$ before the ginger use $(\mathrm{MH}=$ 9.208).

\section{Discussion:}

Nausea and vomiting are common side-effects of cytotoxic treatment. They continue to affect a significant proportion of patients despite the widespread use of antiemetic medication. They are complex protective mechanisms and the symptoms are influenced by the 
emetogenic response and stimuli. However, when these symptoms recur frequently, they can significantly reduce the quality of life and can also be detrimental to health. The existing antiemetic agents are ineffective against certain stimuli, expensive, and possess side effects (12).

The present study findings revealed that Rhodes Index total Score was significantly decreased after using Ginger tablets. Such findings supported the study hypothesis; utilization of ginger tablets has appositive effect on relieving chemotherapy related nausea and vomiting among patients with gynecological cancer. Moreover our finding revealed that there was a significantly difference, in times feeling nauseated or sick at stomach. This means that treating with ginger improving significantly case of feeling distress and feeling sick at stomach, which is in line with Julie L Rayan, 2012 et al. The authors concluded that ginger $\quad 0.5 \mathrm{~g}, \quad 1.0 \mathrm{~g}$ and $1.5 \mathrm{~g}$ significantly decreased nausea $(p=0.003)$. The highly decreasing in nausea and its intensity achieved with a dose $0.5 \mathrm{~g}$ and $1.0 \mathrm{~g}$ of ginger.

Varied by Rhodes Index Items; the present study finding showed a significant decrease of feeling severe distress after retching, after vomiting and after nausea/ sickness at stomach by $6 \mathrm{hrs}$ and a significant increase in mild- moderate distress after retching; vomiting and nausea, similarly for feeling no distress after retching, vomiting and nausea after using ginger tablets compared to pre using it. Such result is consistence with Pillai , 2011 finding who mentioned that acute moderate to severe nausea was observed in $28 / 30$ (93.3\%) cycles in control group as compared to $15 / 27(55.6 \%)$ cycles in experimental group $(\mathrm{P}=0.003)$ and acute moderate to severe vomiting was significantly more in the control group compared to the experimental group $[23 / 30 \quad(76.7 \%)$ vs. $9 / 27 \quad(33.33 \%)$ respectively $(\mathrm{P}=0.002)]$. Delayed moderate to severe nausea was observed in $22 / 30(73.3 \%)$ cycles in the control group as compared to $7 / 27$ $(25.9 \%)$ in the experimental group ( $\mathrm{P}$ $<0.001)$. Delayed moderate to severe vomiting was significantly more in the control group compared to the experimental group [14/30 (46.67\%) vs. $4 / 27(14.81 \%)(\mathrm{P}=0.022)]$.

Additionally Sontakke et al 2003 demonstrated that the effect of ginger was found to be comparable to that of metoclopramide by which a complete control of nausea was achieved in $62 \%$ of patients who received ginger and $58 \%$ of patients who received metoclopramide which is similar to the present study results which shows that there is a significant difference in decreasing number of times feeling sick at stomach. Sontakke et al also assessed acute vomiting and reported a difference between the anti-emetic effect of metoclopramide and ginger that was not statistically significant (13).

In agreement to our finding Montazeri et al.2013 conducted a randomized, prospective, cross-over double blinded clinical trial hematology patients under chemotherapy treatment. He assigned patients to two regimes A (taken their routine antiemetic drugs along with 
UTILIZATION OF GINGER AND ITS EFFECT ON RELIEVING etc...

4 capsules of ginger each one contain $250 \mathrm{mg}$ ginger powder and ask them to take two capsules $30 \mathrm{~min}$ before chemotherapy treatment and two $6 \mathrm{hrs}$ after) regimes $B$ (taken their routine antiemetic drugs along with 4 capsules of placebo each one contain $250 \mathrm{mg}$ ineffective chikpea powder and ask them to take two capsules $30 \mathrm{~min}$ before chemotherapy treatment and two 6 hrs after). The author concluded that the severity of nausea in patients had regimes $\mathrm{A}$ in the 1st, 2nd, 3rd, 4th hours after chemotherapy treatment and to the end of $24 \mathrm{~h}$ (acute nausea) was reduced $9 \%, 18.2 \%, 13.7 \%$, $22.7 \%, \quad 13.7 \%, \quad 27.3 \%$ respectively, also the severity intensity of nausea is decreased and the severity of vomiting in the 1st, 2nd ,3rd,4th and the end of the day was 9.1, 9.1, 9.1, 4.6, 4.7 respectively was less than placebo. Also Nanthacoma et al 2006 who concluded that nausea was appeared in $48.3 \%$ in ginger group and $66.7 \%$ in placebo group so the ginger was $18.4 \%$ more effective than placebo.

Conversely, Lee and Oh, 2013 in their database search reported that current evidence does not support the use of ginger for the control of CINV. A systematic review was conducted of five randomized, controlled trials involving 872 patients with cancer. Ginger was compared with placebo or metoclopramide. Ginger did not contribute to control of the incidence of acute nausea and vomiting or of the severity of acute nausea.

Moreover, our results are similar to PanahiY etal 2012 in their pilot, randomized, trial on 100 women with breast cancer and initially assigned to standard chemotherapy protocol and women were randomized to the ginger group; receive ginger $(1.5 \mathrm{~g} / \mathrm{d}$ in 3 divided doses every 8 hours) plus standard antiemetic regimen or control group; receive standard antiemetic regimen alone. The duration of treatment with ginger was specified to 4 days from the initiation of chemotherapy. Prevalence, score, and severity of nausea, vomiting, and retching were assessed using a simplified form of Rhodes index in the first 6 hours, between 6 to 24 hours, and days 2, 3, and 4 post chemotherapy. The author concluded a significantly lower prevalence of nausea in the ginger group during 6 to 24 hours post chemotherapy (acute nausea) when added ginger $(1.5 \mathrm{~g} / \mathrm{d})$ on 4 doses four days started from the initiation of chemotherapy to standard antiemetic therapy.

\section{Conclusion:}

The present study findings indicated that All the Rhodes Index items were highly significantly decreased after receiving the ginger tablets compared to before receiving $(\mathrm{p}<0.001)$. Thus

\section{Recommendations:}

Based on the findings of this research, these recommendations are suggested:

- Community raising program about the efficacy of ginger for those patients with gynecological cancer under treatment of chemotherapy to enhance them to utilize ginger to relieve nausea and vomiting through T.V scenario as well as counseling and health education

- Raising the awareness of nurses and the other health care providers about the safety and efficacy of the ginger tablets on relieving the 
chemotherapy related nausea and vomiting.

- Designing and implementing ginger tablets dosing schedule for relieving the chemotherapy induced nausea and vomiting.

- Dissemination the present study findings to all Gynecological departments at El Mansoura, Qalupia and Monofia governorate to sensitize health team to utilize ginger for patients with gynecological cancer under treatment of chemotherapy to relieve nausea and vomiting.

- Future research needed to investigate the efficacy of other herbs on the chemotherapy related nausea and vomiting is recommended.

\section{References:}

1- Marx, Wolfgang M, Laisa Teleni, Alexandra L McCarthy, Luis Vitetta, Dan McKavanagh,Damien Thomson, and Elisabeth Isenring." Ginger (Zingiber officinale) and chemotherapy- induced nausea and vomiting:a systemic literature review", NutritionReviews, 2013.

2- wikipedia.org

3- Hilarius, D.L., Kloeg, P.H., van der Wall, E., van den Heuvel, J.J.G., Gundy, C.M., \& Aaronson, N.K. (2012). Chemotherapy-induced nausea and vomiting in daily clinical practice: a community hospital based study. Support Care Cancer, 20. 107117. doi: 10.1007/s00520-0101073-9.
4- Marx W1, McCarthy AL, Ried K, Vitetta L, McKavanagh D, Thomson D, Sali A, Isenring L.Can ginger ameliorate chemotherapy-induced nausea? Protocol of a randomized double blind, placebo-controlled trial. ANZCTR. org. au Identifier: ACTRN12613000120774. PMID: 24712653[PubMed - in process] PMCID: PMC3984021: 2014 Apr 9;14:134. doi: 10.1186/1472-688214-134.

5- Roscoe JA, Morrow GR, Colagiuri B, Heckler CE, Pudlo BD, Colman L, Hoelzer $\mathbf{K}$, Jacobs A. Insight in the prediction of chemotherapy-induced nausea. Support Care Cancer. 2010;18:869-876. doi: 10.1007/s00520-009-0723-2.

6- National Cancer Institute. Nausea and Vomiting PDQ ${ }^{\circledR}$ last modified 9/28/12. Accessed at www.cancer.gov/cancertopics/pdq/ supportivecare/nausea/Patient on February 11,2013.

7- Kamen C, Mohamedtaki A. Tejani, KavitaChandwani,Miche le Janelsins, Anita R.Joseph A. Roscoe,and Gary R. Morrow, MS Anticipatory nausea and vomiting due to chemotherapy: Eur J Pharmacol. Author manuscript; available in PMC 2014 Jan 5.

8- Grunberg S, Chua D, Maru A, et al. Single-dose fosaprepitant for the prevention of chemotherapyinduced nausea and vomiting associated with cisplatin therapy: randomized, double-blind study protocol--EASE. J Clin Oncgol 2011; 29:1495-1501. 
UTILIZATION OF GINGER AND ITS EFFECT ON RELIEVING etc...

9- Chung, S. K., Ahn, M. J., Yoo, J. Y., Choi, M., Hyang, N., Woo, S. R., Oh, E. G. (2011). Implementation of best practice for chemotherapy-induced nausea and vomiting in an acute care setting. International Journal of EvidenceBased Healthcare, 9, 32-38. doi: 10.1111/j.1744-1609.2010.00198.

10- Aranda, S, Jefford, M, Yates, P, Gough, K, Seymour, J, Francis, $\mathbf{P}$ (2012) Impact of a novel nurseled prechemotherapy education intervention (ChemoEd) on patient distress, symptom burden, and treatment-related information and support needs: results from a randomised, controlled trial. Ann Oncol 23: pp. 222-231

11- Ryan JL, Heckler CE, Roscoe JA, Dakhil SR, Kirshner J, Flynn PJ, Hickok JT, Morrow GR. Ginger (Zingiber officinale) reduces acute chemotherapyinduced nausea: a URCC CCOP study of 576 patients. Support Care Cancer. 2012;20:1479-1489. doi: $10.1007 / \mathrm{s} 00520-011-1236-3$. [PMC free article] [PubMed] [Cross Ref

12- Palatty PL1, Haniadka R, Valder B, Arora R, Baliga MS, (2013) : Ginger in the prevention of nausea and vomiting: a review; 53(7): 659-69. doi: 10.1080/10408398.2011.553751.

13- Haniadka R1, Rajeev AG, Palatty PL, Arora R, Baliga
MS,2012. Impact of Zingiber

officinale (ginger) as an antiemetic in cancer chemotherapy: a review. ;18(5):440-4. doi: 10.1089/acm.2010.0737. Epub 2012 Apr 27.

14- Pillai AK, Sharma KK, Gupta YK, Bakhshi S. Anti-emetic effect of ginger powder versus placebo as an add-on therapy in children and young adults receiving high emetogenic chemotherapy. Pediatr Blood Cancer. 2011;56:234-238. doi: 10.1002/pbc.22778. [PubMed] [Cross Ref]

15- Sontakke S, Thawani V, Naik MS. Ginger as an antiemetic in nausea and vomiting induced by chemotherapy: a randomized, cross-over, double blind study. Indian J Pharmacol. 2003;35:5.

16- Lee J1,OhH. Ginger as an antiemetic modality for chemotherapy-induced nausea and vomiting: a systematic review and meta-analysis: 2013 Mar;40(2):163-70. doi: 10.1188/13.ONF.163-170.

17- Panahi Y, Saadat A, Sahebkar A, Hashemian F, Taghikhani M, Abolhasani E. Effect of Ginger on Acute and Delayed ChemotherapyInduced Nausea and Vomiting: A Pilot. Open-Label Clinical Trial. Integr Cancer Ther: Randomized; 2012 